\title{
La imagen del «moro» en la formulación e instrumentalización del africanismo franquista
}

\author{
Rocío Velasco de Castro \\ Universidad de Extremadura
}

RESUMEN: Este artículo pretende analizar el discurso ideológico sobre el que se cimentó la política colonial franquista en Marruecos, y especialmente la recuperación e instrumentalización de la imagen del «moro» para la supervivencia y consolidación de la Dictadura que dio lugar al llamado "protectorado sentimental». De su análisis se infieren las bases de la maquinaria propagandística del régimen y su utilización en la política exterior, pero también las contradicciones y el doble juego desplegado por Franco con respecto a Marruecos y a los países árabes.

\section{Palabras clave: Marruecos; Política colonial; Protectorado senti- mental; «moro»; Franquismo.}

The «moro» image and the filing and handling of Franco's regime africanism

ABSTRACT: This article attempts to analyze the ideological discourse in which Franco regime's colonial policy in Morocco was based on, and specially the recovery and manipulation of «Moro» conceptualization in order to get the survival of Dictatorship and its consolidation which gave place to the "sentimental protectorate". From its consideration we can infer the basis of Franco's propaganda machinery and its use in Spanish foreign policy, but it also shows the contradictions and double game played by Franco regarding to Morocco and the Arabic countries.

KeY WORDS: Morocco; Colonial Policy; Sentimental Protectorate; "Moro"; Franco's regime. 


\section{INTRODUCCIÓN}

Al igual que las fronteras físicas suelen delimitarse en virtud de la geografía, las fronteras ideológicas suelen establecerse en virtud de una alteridad, real o imaginaria, que refuerce identitariamente al colectivo o sociedad en cuestión. Dicha alteridad puede entrañar aspectos positivos de intercambio y enriquecimiento cultural, pero también negativos de exclusión y oposición. En cualquier caso, se trata de unas fronteras permeables, cambiantes y sometidas en muchas ocasiones a una determinada intencionalidad política.

En la cuestión que nos ocupa, la gestación de la identidad nacional en un ambiente bélico como fue la conquista de la Península por los reinos cristianos, se estableció en base a unos planteamientos reduccionistas, en clave opositora y excluyente, con los que identificar fácilmente a nuestro vecinoenemigo más cercano. De esta forma, al musulmán, al africano, al morisco, al marroquí, se le adjudicaron una serie de rasgos negativos que van desde lo físico hasta lo moral e intelectual, y cuya máxima representación actual es la pervivencia y el uso peyorativo del término «moro».

Dichos estereotipos no sólo permanecieron en el imaginario colectivo durante los siglos posteriores, sino que se consolidaron como consecuencia de las vicisitudes históricas que caracterizaron las relaciones entre ambas orillas. Entre ellas, podemos mencionar la rivalidad hispano-portuguesa por la conquista de las costas norteafricanas (1458-1510), el espíritu de cruzada que se desprendía del famoso testamento de Isabel la Católica (1504), las campañas militares españolas producto de la dinámica expansionista del imperialismo europeo (1859-1927), la participación de los marroquíes en la guerra civil (1936-1939), y el conflicto del Sáhara (1975). A ellas cabe sumarse la reformulación que desde la caída del Telón de Acero se ha ido configurando en torno al binomio opositor Islam-Occidente y a la asociación de un Islam monolítico y homogéneo con la inmigración ilegal y el terrorismo ${ }^{1}$.

De todo este recorrido, vamos a centrarnos en el período que transcurre entre la implantación del Protectorado en Marruecos y la postguerra mundial. Se trata de unos años en los que la frontera ideológica en torno al «moro» se desarrolló bajo unos parámetros caracterizados por la pervivencia de clichés anteriores, su reformulación para que sirvieran a los objetivos políticos del primer franquismo, y los discursos paralelos generados desde la oposición al bando nacional y al posterior gobierno franquista.

Para entender la construcción, deconstrucción y re-elaboración de esta frontera ideológica, hemos de tener en cuenta dos elementos fundamentales. El primero es el triunfo de la sublevación militar, al que contribuyó decisiva-

1 La evolución de esta percepción es analizada, entre otros, por MORALES LEZCANO, 1993 y MARTÍN CORRALES, 2002 b. 
mente el contingente de tropas marroquíes que combatieron en el bando nacional. El segundo factor es la necesidad del régimen en consolidarse y en obtener el apoyo de los países árabes para salir del ostracismo internacional al que fue condenado tras la finalización de la Segunda Guerra Mundial. De ambos factores se colige que la fluctuación de la frontera ideológica estuvo supeditada a los intereses del régimen y al utilitarismo del que Franco hizo gala, gracias al cual logró mantenerse en el poder durante casi cuarenta años.

\section{LAS FUENTES DEL AFRICANISMO FRANQUISTA: EL ARABISMO Y EL AFRICA- NISMO DECIMONÓNICOS}

El pragmatismo que caracterizó el discurso oficial de los sublevados les llevó a adoptar en el Norte de África una política de atracción de las autoridades indígenas, cuya actuación resultaría crucial para el desenlace de los acontecimientos dentro y fuera del protectorado. Finalizada la contienda, y por estricta conveniencia de los intereses del régimen, tanto a nivel nacional como internacional, dicha política continuó cultivándose con especial fruición, hasta tal punto que las concesiones a las demandas planteadas por los nacionalistas marroquíes en cuanto a libertad de prensa y asociación, no llegarían a implantarse en la metrópoli². Con la aplicación de éstas y otras medidas, el protectorado español se convertía en la imagen más amable del franquismo y, por tanto, en el escaparate que debía mostrarse al exterior, especialmente a los países árabes, uno de los tres pilares junto a Hispanoamérica y el Vaticano, sobre los que se desarrollarían las llamadas «políticas de sustitución» del régimen durante su condena internacional ${ }^{3}$.

Dicho proceder implicaba, desde el punto de vista conceptual, una reelaboración de la noción de protectorado que distinguiera y favoreciera la gestión colonial española en el territorio, lo que dio lugar a la imposición de un discurso oficial repleto de una serie de imágenes, analogías y eufemismos con claros tintes propagandísticos. La gestación y desarrollo de esta reformulación corrió a cargo de un grupo de ideólogos, quienes bebieron de buena parte de los planteamientos defendidos por el orientalismo africanista del siglo XIX en sus distintas tendencias ${ }^{4}$.

A su vez, muchos de estos africanistas decimonónicos se habían servido de la labor emprendida por el arabismo para sustentar sus argumentaciones. En

2 Véase el análisis de IBN AZZUZ HAKIM, 1999a: 54-55.

3 Para un estudio pormenorizado de la cuestión: ALGORA WEBER, 1995.

4 Para un análisis detallado sobre la gestación y evolución del africanismo español, véanse MORALES LEZCANO, 11 (Madrid, 1990): 17-34; 1988. GIL GRIMAU, 1988, vol. 3: $277-285$. 
consecuencia, los estudios centrados en al-Andalus realizados por Gayangos, Simonet, Lafuente Alcántara, Codera y Zaidín o Miguel Asín Palacios entre otros, fueron adoptados y empleados como elementos legitimadores de las propuestas africanistas formuladas por Costa o Donoso Cortés ${ }^{5}$. Estos últimos, al adecuar a su conveniencia los estudios en torno a la civilización andalusí, no sólo establecían un discurso colonial español legitimista, sino que evidenciaban la interrelación existente entre el arabismo y las políticas imperialistas y nacionalistas de la época ${ }^{6}$.

Siguiendo esta línea argumental, los africanistas del franquismo recuperaron, más de medio siglo después, muchos de los planteamientos del africanismo decimonónico finisecular. Con ello retomaban la producción arabista cuyos aspectos más idílicos en torno a la civilización andalusí no dudaron en sobredimensionar a través de la perpetuación de una serie de tópicos sobre los que se gestó la «hermandad hispano-marroquí». En virtud de la permeabilidad y capacidad de adaptación de dichos presupuestos a los intereses políticos del franquismo, y muy especialmente a los presupuestos imperialistas promovidos por el fascismo, la profusión con la que se difundió la ideología oficial del régimen condujo a que el africanismo gozara de un impulso sin precedentes durante el primer franquismo y, por ende la imagen del «moro», eje vertebrador del mismo.

De hecho, incluso durante la guerra civil, la aparente ruptura con respecto al tradicional discurso sobre Marruecos y los marroquíes, no supuso más que una continuidad de dicha percepción, si bien esta última debía ser solapada a través de la potenciación de los elementos andalusíes con una finalidad puramente militar: la de contar, por un lado, con el protectorado como retaguardia $\mathrm{y}$, por otro, con la participación de un elevado número de sus habitantes en los combates peninsulares, donde fueron utilizados como fuerzas de choque.

Por lo tanto, y en función de la adopción, en algunos casos re-elaboración, de los argumentos expuestos por los africanistas y arabistas del siglo XIX, se procedió a justificar el alistamiento de tropas indígenas y la política imperialista ejercida a través del protectorado marroquí, cuya labor no se desarrollaría en términos impositivos o de superioridad, sino de colaboración y hermanamiento entre dos pueblos que compartían un importante legado cultural e histórico ${ }^{7}$. Bajo esta fórmula, que trataba difícilmente de conciliar las aspiraciones del régimen con algunas de las demandas del nacionalismo marroquí y con la llamada «política árabe del franquismo» practicada durante el aislacionismo de postguerra, se desarrollaría un amplio corpus en el que, hasta 19391940, primó el empleo de conceptos como «hermandad hispano-marroquí» o

5 Para más información: PARRA MONSERRAT, 2010.

6 Véase como ejemplo VELASCO DE CASTRO, 22 (Cáceres, 2010): 245-262.

7 MATEO DIESTE, 2003: 451. 
«protectorado sentimental», eufemismos con los que se definió la gestión colonial de las autoridades franquistas.

\section{LA «RECONVERSIÓN» DE LOS MILITARES AFRICANISTAS: DE LA MOROFOBIA A LA MOROFILIA}

Esta última cuestión nos lleva a retomar el trasfondo ideológico que subyacía bajo esta redefinición de la política colonial. Las consignas que conformaban el discurso oficial, como hemos mencionado en las líneas anteriores, fueron elaboradas y difundidas con la única finalidad de utilizarse políticamente en beneficio de los intereses del franquismo. Por lo tanto, la amplia literatura en torno a la supuesta morofilia e islamofilia de los oficiales africanistas, empezando por el propio Franco, ha de contextualizarse en la campaña de atracción de las autoridades indígenas, es decir, en la línea de actuación que buscaba, por encima de todo, el éxito del golpe de Estado y la supervivencia del régimen.

Recordemos que, en la España de la época, los prejuicios en torno al mundo árabe e islámico se encontraban bastante enraizados entre la población. Esta imagen negativa, cuya génesis puede situarse en el espíritu de cruzada de la «Reconquista», habría generado una serie de estereotipos en torno al morisco y al «moro», posteriormente reforzados durante las campañas de Marruecos, y muy especialmente, tras el desastre de 1921, que desencadenó uno de los momentos más álgidos de esta tendencia morofóbica ${ }^{8}$.

El comportamiento de los «moros amigos» durante el episodio de Annual fue interpretado como una traición a España, lo que generó la desconfianza hacia el colectivo y el retorno a los planteamientos xenófobos basados en la barbarie e inferioridad del «moro», al que contribuyeron de manera decisiva muchos militares africanistas. Éstos últimos, para justificar sus actuaciones en el territorio, desplegaron en torno a Revista de Tropas Coloniales y su continuación, África, su particular decálogo en torno a la personalidad y costumbres del «moro».

Así, la lectura de la revista África en su edición de febrero de 1924, incidía en el hecho de que la idiosincrasia del «moro» era «tornadiza por naturaleza» ${ }^{9}$, acorde a su condición de «hombre primitivo incapaz de comprendernos en nuestra potencia actual de civilización, porque él está aún algunos cientos de años separado de ella» ${ }^{10}$. En consecuencia,

8 BARCIA, 3 (Ceuta, 1924): 9, sitúa la génesis del «terror al moro» y el «odio al moro» en la Reconquista, y atribuye su consolidación a la guerra de África.

9 RUIZ TRILLO, 2 (Ceuta, 1924): 6.

10 RUIZ TRILLO, 2 (Ceuta, 1924): 7. 
no se someten más que cuando están dominados. Y como no tienen riquezas que puestas en peligro los coaccionen, ni organizaciones que puedan ser destruidas, ni sensibilidad que pueda ser herida, ni opinión pública que llegue a un estado de renuncia y vencimiento, hay que dominarlos personalmente, primitivamente, psicológicamente $^{11}$.

En suma, «los moros, pues, no son más buenos ni más malos que los demás mortales, si bien sus instintos se manifiestan, en proporción a su menor cultura, con mayor intensidad salvaje» ${ }^{12}$.

A tenor de estas afirmaciones, que se repiten de manera reiterativa a lo largo de los diferentes números de la publicación, hay quien afirma que los militares africanistas eran profundamente arabófobos, incluyendo al coronel Beigbeder, quien a pesar de cultivar una imagen pública de amante de la cultura y tradición árabes, se habría burlado en alguna ocasión de los caídes marroquíes, «a los que consideraba vulgares y ridículos» ${ }^{13}$. En similares términos se habían expresado algunos de los más destacados militares africanistas como Berenguer, Mola, o el propio Franco. Durante las campañas del Rif y Yebala, el general Berenguer reproducía los clichés en torno a los musulmanes de al-Andalus y los aplicaba a los marroquíes del Protectorado, a los que criticaba su desmesurada codicia y su falta de principios $^{14}$.

Por su parte, Mola no tenía mejor concepto de sus antiguos subordinados, los Regulares. Citaba a Cervantes para afirmar que «de los moros no se podía esperar verdad alguna porque todos eran embelecadores, falsarios y quimeristas $\gg{ }^{15}$. Por si esto fuera poco, en 1926, recomendaba el siguiente procedimiento para evitar emboscadas:

si se encontrase con algún indígena, por inocente que parezca, se le hará prisionero, manteniéndole entre la fuerza emboscada con los ojos vendados, amarrado y convenientemente vigilado, amenazándole con que sería muerto en el acto en el caso de gritar o moverse. Estas medidas son extremadamente violentas, pero en la guerra, y más con los moros, no se puede andar con contemplaciones ${ }^{16}$.

Y, por supuesto, Franco, cuya actitud es definida por algunos autores como «profundamente racista» ${ }^{17}$, ya que «sentía una clara hostilidad hacia todo lo marroquí. Franco jamás llegó a hablar más de cuatro palabras en árabe, y sus concepciones sobre el Magreb se caracterizaban por su tono racista y anti-

11 ACEDO COLUNGA, 4 (Ceuta, 1924): 14.

12 MAESTRE, 4 (Ceuta, 1924): 25.

13 NERÍN, 2005: 207.

14 BERENGUER, 1923: 132.

15 MOLA, 1940: 27.

16 MOLA, 14 (Madrid, 1926): 106.

17 NERÍN, 2005: 205. 
islámico» ${ }^{18}$. En línea con esta descripción, en noviembre de 1926, el entonces teniente general describía al «moro» como «ignorante y apático» ${ }^{19}$, al que «le mueve más el interés que el sentimiento ${ }^{20}$, coincidiendo así en esta última apreciación con Berenguer. Además, calificaba a los beréberes de «fanáticos e impresionables» ${ }^{21}$ y sentenciaba que bastaba «un jefe prestigioso o un santón melenudo para turbar y aún levantar kabilas y aduares» ${ }^{22}$.

Hay incluso quien afirma que «sentía por los obreros de izquierdas el mismo desprecio racista que habían despertado en él las tribus del Rif» ${ }^{23}$. Muestras de esta equiparación la encontramos años después, cuando al plantearse la reforma agraria en el campo andaluz, el gabinete que presidía había llegado a la conclusión de que no se podía hacer nada al respecto: «Los campesinos andaluces son ignorantes, vagos y mala gente. Africanos. Y no tienen una Virgen del Pilar. El Caudillo no puede hacer nada» ${ }^{24}$. Menos de una década después, todos ellos profesarían públicamente una cuanto menos sorprendente morofilia en consonancia con el discurso oficial de los nacionales, quienes en el momento de la sublevación necesitaban propugnar en el Norte de África la «hermandad hispano-marroquí» y erigirse en los representantes de dicha confraternidad a través del ejercicio de un «protectorado sentimental», como veremos en las páginas siguientes.

Cabe concluir, por tanto, que la adopción de una línea discursiva opuesta a la defendida con anterioridad en torno al «moro» y contraria también, en principio, a las convicciones personales de quienes se erigieron en sus máximos representantes, obedecería a las necesidades del momento. Sólo así podría explicarse la gran paradoja que supuso la unión de caudillos marroquíes y militares españoles que apenas una década anterior habían sido enemigos irreconciliables, pues muchos de ellos se habían enfrentado en la mal llamada «campaña de pacificación» (1909-1926), y el hecho de que esos mismos militares que contribuyeron a cimentar los prejuicios contra el «moro», protagonizaran ahora un discurso de hermanamiento y gratitud a los mismos que habían vilipendiado y ajusticiado años antes.

Por otra parte, como afirma Balfour, «el discurso colonial marcó el discurso de la guerra civil en relación sobre todo al Otro $»^{25}$. En consecuencia, la participación de los marroquíes en la guerra civil propició la confrontación de

18 NERÍN y BOSCH, 2001: 66.

19 FRANCO, 21 (Madrid, 1926): 266.

20 FRANCO, 21 (Madrid, 1926): 266.

21 FRANCO, 4 (Ceuta, 1924): 4.

22 FRANCO, 4 (Ceuta, 1924): 4.

23 EGIDO y ARÓSTEGUI, 2006: 100.

24 JACKSON, 2008: 116.

25 BALFOUR, 2003: 95. 
los bandos también en este aspecto, pues provocó la coexistencia de los usos contrapuestos de la figura del «moro»: la tradicional, de rechazo y profunda aversión que manifestaba la propaganda republicana de la época, frente a la de camaradería y hermandad difundida por los sublevados ${ }^{26}$. Aún en este último caso, la visibilidad de estas alianzas coyunturales contribuyó a sustentar el estereotipo ya apuntado por Mola en Tropas Coloniales del «moro» como un personaje «lleno de dobleces, en el que no se podía confiar lo más mínimo» ${ }^{27}$, en la línea de los cabecillas Raisuni y Abdelkrim. A este respecto, conviene advertir que el recuerdo de la represión de la revuelta asturiana de 1934 a manos del Ejército de África estaba aún bastante reciente en la Península, y había generado una corriente de gran impopularidad respecto al «moro" entre las clases obreras, en su mayor parte afectas a la República ${ }^{28}$.

De forma que, el uso de las tropas marroquíes en la Península durante la guerra civil por parte de las autoridades franquistas fue empleado, además de como carne de cañón, como factor psicológico con el que se alimentó y reforzó esta visión de mercenarios crueles y despiadados a los que se les permitían las razias, se les instaba a asolar las zonas conquistadas y se les ordenaba ajusticiar a los prisioneros mediante el ejercicio de lo que eufemísticamente denominaban "operaciones de limpieza y castigo» ${ }^{29}$. Un procedimiento que anteriormente se había ejercido contra los marroquíes durante la «campaña de pacificación ${ }^{30}$.

Dichas prácticas, además de facilitarles un medio para vengarse de las afrentas recibidas durante las citadas campañas, contribuyeron a alimentar el terror a las fuerzas de choque de los nacionales y, sobre todo, permitieron eliminar cualquier atisbo de oposición que pudiera darse en la zona conquistada $^{31}$. Actuaciones como las mostradas durante la toma de Andalucía y Extremadura cimentaron considerablemente esta aversión, al tiempo que impulsaron el desarrollo de una activa campaña propagandística para encubrir buena parte de las atrocidades cometidas con el fin de evitar sus posibles efectos en la esfera internacional ${ }^{32}$.

En algunos casos, los testimonios fueron manipulados o sobredimensionados, bien para infundir terror sobre los republicanos ${ }^{33}$, bien para mostrarlos

26 MATEO DIESTE, 1997: 58.

27 CASTIÉN, 2007: 72.

28 IBN AZZUZ HAKIM, 1997: 77.

29 Mencionadas, entre otros, por BALFOUR, 2002: 523 y 538-541. MADARIAGA, 2003: 63. PRESTON, 1998a: 72.

30 BALFOUR, 2003: 97.

31 PRESTON, 1998a: 209.

32 BALFOUR, 2002: 545.

33 Véanse al respecto MADARIAGA, 46 (Madrid, 1988): 509-520; 2002: 296-316. MARTÍN CORRALES, 2002a: 221-236; 2002b: 151-178. MATEO DIESTE, 1997: 59. 
como ejemplo de la barbarie que encarnaba el franquismo ${ }^{34}$; en otros, la permisividad de buena parte de los oficiales españoles, que se habían formado en las campañas de Marruecos, obedeció al hecho de que «concebían la lucha contra el «rojo» en la Península como una prolongación de la guerra colonial contra el «rebelde rifeño» ${ }^{35}$. Sin embargo, y a pesar de emplearse esta misma mecánica, las atrocidades no se medían por el mismo rasero cuando las víctimas eran campesinos marroquíes que cuando eran españoles. De forma que el estereotipo del «moro» asumió las prácticas más execrables, especialmente centradas en mutilaciones y violaciones, aunque éstas no hubieran sido patrimonio exclusivo de los marroquíes. Quizá uno de los casos más representativos sea el del general Mizzián prototipo, en sendos casos, de la actuación del «moro» durante el conflicto ${ }^{36}$. El efecto fue tal, que en algunos puntos de nuestra geografía española, especialmente en las zonas rurales donde actuaron estas fuerzas indígenas, aún permanece esta imagen del «moro» en el imaginario colectivo como sinónimo de terror y barbarie ${ }^{37}$.

En otro nivel, pero siguiendo la misma línea de actuación, la apropiación simbólica de esta imagen de respeto y temor que infundía la llamada «Guardia Mora» (integrada por tropas del $2^{\circ}$ escuadrón de Regulares de Tetuán) de la que Franco se hacía rodear, constituye un claro ejemplo de la manipulación e instrumentalización ideológica de la imagen del «moro» y de sus efectos, tanto entre la población española (de rechazo) como entre la marroquí (de atracción al franquismo). Y lo mismo cabría decir de atribuciones como la conocida baraka del general, también explotada con la misma finalidad: la pretendida invencibilidad en clave republicana, y liderazgo como caudillo del Islam (al estilo de Raisuni o de tantos otros guerreros célebres defensores de las costumbres islámicas), en clave marroquí.

34 Véase los ejemplos que recoge NERÍN, 2005: 209-210.

35 BALFOUR, 2002: 524. MADARIAGA, 2003: 87. Las semejanzas en los métodos de actuación, tanto tácticos como de represión y ajusticiamiento de las víctimas, especialmente durante los primeros meses de la guerra, resultan más que notables. Autores como BALFOUR, 2003: 95-110. MADARIAGA, 2003: 58-94. MERROUN, 2003. PRESTON, 1997; 1998a, recogen numerosas muestras de esta conducta entre las fuerzas y tropas integrantes del Ejército de África.

36 Véase su actuación junto al bando nacional en MERROUN, 2003: 106-108. Por lo que respecta a las actuaciones que contribuyeron a gestar el miedo al «moro», véanse MARTÍN CORRALES, 2002a: 221-236. NERÍN, 2005: 286-288. Estas prácticas, comunes a ambos bandos, fueron convenientemente identificadas por republicanos y nacionales con el colectivo marroquí. Los primeros, como símbolo del salvajismo de los nacionales, mientras que los segundos, lo emplearon como factor de terror psicológico contra el enemigo.

37 MADARIAGA, 2003: 89. IBN AZZUZ HAKIM, 1997: 80. Para un análisis más completo de la cuestión, véanse los estudios de GONZÁLEZ ALCANTUD, 2002. GOYTISOLO, 1982. MATEO DIESTE, 1997. MADARIAGA, 46 (Madrid, 1988): 509-520. MARTÍN CORRALES, 2002a: 221-236. 


\section{EL «PROTECTORADO SENTIMENTAL» DE BEIGBEDER Y LA «HERMANDAD HIS- PANO-MARROQUÍ»}

Mientras en la Península nacionales y republicanos potenciaban la atribución de los más abominables y violentos comportamientos a las tropas marroquíes que participaban en la contienda, en la zona de protectorado, retaguardia de los militares sublevados y principal fuente de abastecimiento militar del bando nacional, los responsables coloniales franquistas se esforzaban en promocionar una imagen totalmente contraria del marroquí. Dicha imagen fue especialmente difundida a través de los lemas y consignas dirigidos a las campañas de reclutamiento ${ }^{38}$, que se combinaban con medidas coercitivas y con la represión y arrestos preventivos de todos los que pudieran resultar sospechosos de atentar contra las nuevas autoridades españolas.

Estas últimas se sirvieron de la recuperación e idealización del pasado común, en el que los andalusíes dominaban el Estrecho y la civilización musulmana había conquistado buena parte del mundo conocido, para construir la base de un discurso caracterizado por la evocación de las glorias pasadas y la preeminencia cultural de al-Andalus. Ambos argumentos fueron hábilmente instrumentalizados para escenificar el reencuentro de ambos pueblos en beneficio de los militares golpistas. Con dicha finalidad, el general Franco envió a Marruecos al coronel Juan Beigbeder, del que se ha dicho que «se consideraba un discípulo aventajado de Lyautey» ${ }^{39}$, pues trató de ejercer en sus distintos cometidos la política indígena practicada por el mariscal ${ }^{40}$.

La admiración de la retórica, habilidad y pragmatismo con los que Lyautey ejecutaba las directrices de una política indígena utilitarista y promocional, podría hacerse extensiva a gran parte de la plana mayor de militares formados en el Norte de África. De hecho, no resultaba extraño que uno de los principales pilares de la política indígena del franquismo, como lo fue Beigbeder, procediera siguiendo las directrices del «lyauteismo» al adaptar el concepto de protectorado y su articulación práctica sobre el territorio a los intereses particulares de los amotinados mediante un discurso paternalista y firme, pero amable ${ }^{41}$. Una característica que definirá la relación de las autoridades fran-

38 ASÍN PALACIOS, 1948: 125-152. BENJELLOUN, 2003: 42-57.

39 PAZ, 2000: 61.

40 RUIZ BRAVO-VILLASANTE, 1993: 232, n.1. Sobre la actuación del general Capaz, contamos con su diario, traducido parcialmente al árabe por el historiador Ibn Azzuz Hakim quien alberga en su archivo privado el manuscrito original.

41 Para profundizar en el pensamiento colonial del mariscal, consúltese la recopilación de documentos personales publicada por su hijo: LYAUTEY, 1953. Para un análisis detallado de su actuación como responsable de la política colonial francesa, véase VERNIER, 1993. 
quistas del Protectorado con los representantes del majzén jalifiano y con los nacionalistas marroquíes.

De esta forma, el principal artífice de la reconversión, un militar culto y de formación arabista, acuñaba una de las primeras nociones que convertirían la política del nuevo régimen en un decálogo de la «hermandad» hispanomarroquí: el «protectorado sentimental». Una de las mejores muestras del maquiavelismo político y diplomático desplegado por Beigbeder ${ }^{42}$ la encontramos en su conocida alocución de 1940 en la que, como en ocasiones anteriores, se dirigía a los marroquíes en los siguientes términos: «El Protectorado de Franco es un Protectorado sentimental y no político, y cuando piensa en la conquista es en la conquista de los corazones $\rangle^{43}$. Se producía así la primera desvinculación ideológica con respecto al colonialismo ejercido por otros países, especialmente por Francia, cuya finalidad imperialista se oponía ahora al pretendido altruismo español. En virtud de este planteamiento, la «ingente obra de paz y de civilización que España acometió en Marruecos» se encontraba «totalmente desprovista de mezquinos intereses» ${ }^{44}$.

Uno de los más destacados africanistas del régimen, Enrique Arqués, incidía en 1956, en los fundamentos históricos sobre los que se había fundamentado esta nueva concepción:

España no trajo nunca a sus renombradas empresas de África ningún afán de dominio, ni de revancha, ni de explotación. No vino a buscar riquezas ni a esclavizar a nadie. No quiso tampoco arrebatar tierras ajenas ni sojuzgar libertades tradicionales. España obró casi siempre a la fuerza, empujada por las vicisitudes históricas, por imperativos deberes nacionales, para mantener la integridad de sus propias fronteras, para defender sus costas de la piratería, para asegurar paso franco por nuestros mares a los navegantes de todas las banderas del comercio libre ${ }^{45}$.

Reproducía así las mismas líneas ideológicas que, diecisiete años atrás, el general Franco había puesto de manifiesto durante la entrevista mantenida con el conocido periodista libanés Amin al-Rihani:

Hemos entrado en Marruecos obligados. Lo hemos hecho mediante la fuerza. Al principio defendimos los derechos del Sultán y de los marroquíes, durante algo más de cincuenta años. Pero cuando vimos que los Estados europeos conspiraban contra el país intentando colonizarlo nos vimos obligados a conservar nuestra posición en él. Pero no hemos entrado en Marruecos como un colonialista explotador.

42 Para más información al respecto, véase el análisis de HALSTEAD, 37/1 (Ohio, 1974): 46- 66.

43 BEIGBEDER ATIENZA, 1940: 3 y 7.

44 FERRANDO DE LA HOZ, 1949: 29.

45 CORDERO TORRES, 35 (Madrid, 1956): 25. 
Nuestro objetivo no es el interés material, sino que radica en el bien de los marroquíes y la colaboración con ellos para vigorizar la marcha de sus asuntos ${ }^{46}$.

En virtud de esta reinterpretación, España habría transformado la imposición de permanecer en Marruecos en un derecho histórico, y las ambiciones imperialistas del régimen colonial en una labor desinteresada de ayuda al pueblo marroquí. El protectorado de España en Marruecos se transformaba así en un protectorado espiritual basado en una «misión de paz, de amor, de protección ${ }^{47}$, que se tradujo en una empresa civilizadora centrada en el desarrollo cultural, aunque también en el progreso económico y social de los habitantes de la Zona. Una gestión colonial que Beigbeder resumía, en 1939, en los siguientes términos:

Siguiendo las instrucciones del Caudillo, se ha dado desarrollo inusitado a las instituciones de enseñanza y fomento a la Prensa (...) Y como nuestro protectorado sentimental tiene como nervio el amor al pueblo marroquí, tuvo la prueba al ver las instituciones de carácter social, tales como los reformatorios, las casas baratas, la orientación original de nuestro sistema de prisiones, y esos focos de civilización y cultura que son las Intervenciones, a cargo de oficiales del Ejército español ${ }^{48}$.

De esta forma, el supuesto altruismo de la gestión colonial no era ya sólo concebida como la respuesta española a una situación impuesta por terceros países, sino que se trataba de un derecho legitimado a través del deber de reinstaurar los pilares sobre los que se cimentó la civilización andalusí, consustancial a ambos pueblos, y cuya preeminencia cultural durante siglos pretendía ahora emularse a través de una activa política en este ámbito.

En consecuencia, la sobredimensión intencionada de los tópicos sobre el pasado andalusí llevaba a dar un paso más en la reformulación de la misión española en Marruecos. En línea con las consignas difundidas durante las campañas de reclutamiento de tropas indígenas:

El Protectorado sentimental que es reflejo de una España imperial, no busca la conquista utilitaria, ni primeras materias, ni explotación de los hombres, ni de las cosas; aspira a algo más: a la restauración de un mundo ideal, hoy día en decadencia. Es nada menos que el renacimiento de la cultura árabe, del sentimiento árabe, de las letras árabes y de una civilización que forma parte integrante de España. Queremos que Córdoba resucite de sus cenizas, que enfriaron los siglos 49 .

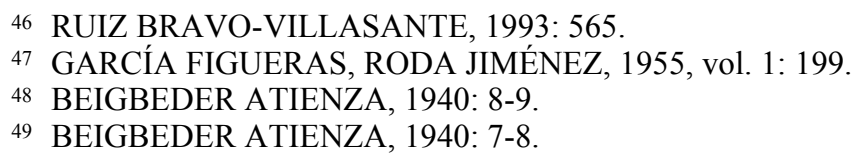


La instrumentalización de la política cultural como elemento conciliador con Marruecos y el mundo árabe, pero al mismo tiempo legitimador de la España imperial a la que hace referencia el fragmento, resulta más que elocuente y resume la práctica de las autoridades franquistas en el territorio.

En cuanto a la alusión a la restauración de un mundo ideal, al renacimiento cultural y a la recuperación del mito de al-Andalus — con el esplendor de la Córdoba omeya como paradigma-, evidenciaban, por un lado, la habilidad de Beigbeder para imbricar un discurso efectista para consumo interno de los árabes dentro y fuera de la Zona, y por otro, la influencia que había ejercido el africanismo y el arabismo decimonónicos en la elaboración del ideario africanista del régimen. De hecho, el empleo del pasado andalusí como elemento consustancial y vínculo indisoluble entre ambos pueblos fue incorporado al conjunto de argumentaciones que no sólo explicaban, sino que prácticamente demandaban la presencia española en el norte de África. Surgía entonces otro componente rescatado del siglo anterior: el pasado compartido como elemento legitimador de los derechos históricos españoles sobre el territorio ${ }^{50}$. A él se sumaban factores geográficos, etnográficos $\mathrm{y}$, por supuesto, culturales.

Una de las mejores muestras del determinismo con el que se definía la misión civilizadora de España como una vinculación natural e histórica en sus relaciones con el pueblo marroquí, lo encontramos en la conocida alocución de Joaquín Costa en el teatro Alhambra en 1884:

Marruecos cumplió en la Edad Media el destino providencial de fundar una civilización en nuestra Península, y España tiene en la Edad Moderna la misión providencial de promover una civilización en Marruecos 51 .

La providencia de este «simpático protectorado sentimental», de la que se hicieron eco los llamados cronistas aúlicos del régimen, representados en el grupo formado por Enrique Arqués, José $\mathrm{M}^{\mathrm{a}}$ Cordero Torres, Tomás García Figueras y José Díaz de Villegas, ya había sido empleada para definir el deber que tenía España con los países de habla castellana ${ }^{52}$. Un deber espiritual basado en la lengua, historia y cultura compartidas, pues España:

50 Véanse al respecto José $\mathrm{M}^{\mathrm{a}}$ Cordero Torres, Enrique Arqués y Tomás García Figueras. El primero rechaza cualquier evocación sentimental del pasado y afirma que se trata de una realidad (CORDERO TORRES, 1941: 21); incide en el desinterés de la política cultural española (CORDERO TORRES, 1949: 86); y subraya los derechos históricos de España sobre Marruecos y su consiguiente misión civilizadora en el territorio (CORDERO TORRES, 1956: 19). Este último argumento es defendido también por el segundo (ARQUÉS, 1942: 18), y llevada al extremo por el tercero, GARCÍA FIGUERAS, 3 (Madrid, 1934): 60.

51 COSTA, 1951: 12. Fragmento citado por CORDERO TORRES, 1956: 16.

52 Véase como ejemplo BELTRÁN Y DE TORRES, 1931: 77. 
ha marcado su impronta imperial en las rutas y en las tierras del mundo y ha dejado un sello indeleble en veintidós naciones independientes, espera continuar, y continuará majestuosa en el curso de la Historia, su destino universal de civilizadora, esta vez en la siempre enigmática África ${ }^{53}$.

Por otra parte, la impronta imperial del africanismo mostraba cierta consonancia con el nacionalismo fascista que propugnaba la Falange, pues ambos compartían el determinismo geográfico o el concepto de espacio vital como elementos legitimadores de sus presupuestos ideológicos. Por este motivo, la producción africanista se mostró especialmente receptiva a reproducir y ampliar planteamientos anteriores sobre la cuestión:

España y Marruecos son como dos mitades de una unidad geográfica (...) Lo repito: el Estrecho de Gibraltar no es un tabique que separa una casa de otra casa; es, al contrario, una puerta abierta por la Naturaleza para poner en comunicación las dos habitaciones de una misma casa ${ }^{54}$.

Compárese este último fragmento de Costa con las palabras que, sesenta años después, escribía uno de los mayores puntales de la política africana del régimen. En 1942, Tomás García Figueras retomaba la imagen del Estrecho:

El Estrecho de Gibraltar no marca geográficamente el límite de Europa y África; al contrario (...) Nadie que pase el Mediterráneo por Gibraltar puede señalar diferencias geográficas entre el Sur de España y Marruecos 55 .

Ya entre la década de los veinte y los treinta, dicho determinismo había sido llevado a su máxima expresión por el conocido arabista y andalucista Rodolfo Gil Benumeya. Coetáneo de García Figueras, Gil acuñaba la siguiente imagen: «Andalucía y Marruecos son dos mitades de una misma fruta partida» ${ }^{56}$. En este mismo sentido se expresaba el semanario melillense Vida Marroquí en su edición de enero de 1936, cuya portada rezaba: «España solamente por Andalucía podrá penetrar en el alma de Marruecos» $\rangle^{57}$.

Sendas referencias no resultan casuales, pues el determinismo geográfico, histórico y cultural, consustanciales al legado andalusí compartido, conformó una parte importante de los presupuestos ideológicos sobre los que se sustentaron tanto el nacionalismo marroquí como el andaluz. De hecho, los contac-

53 CORDERO TORRES, 1941: 95.

54 COSTA, 1951: 12.

55 GARCÍA FIGUERAS, 1944: 11.

56 CORDERO TORRES, 1956: 19.

57 MARTÍN CORRALES, 2002b: 147. Entre los ejemplos gráficos recogidos por el autor, se muestra la equiparación de «moras» y flamencas andaluzas (Cartel de las grandes fiestas de Melilla, septiembre de 1921, p. 146). 
tos entre los líderes de ambos grupos, Abdessalam Bennuna y Blas Infante, fueron intensos y de gran influencia mutua en sus respectivas percepciones y reivindicaciones políticas ${ }^{58}$. No en balde, buena parte de la elite tetuaní miembro o simpatizante del partido nacionalista era descendiente de los andalusíes expulsados de la Península. Y de hecho, la relación entre los nacionalistas marroquíes y los andalucistas a partir de un ideario político común, contribuyó a que Beigbeder adecuara y empleara estos presupuestos en beneficio del régimen.

Con dicha finalidad, el determinismo histórico, geográfico y cultural que legitimaba la colonización española propugnaba una imagen de pretendida confraternización entre dos pueblos hermanos que fue ampliamente publicitada por la maquinaria propagandística oficial. Esta última, además de generar un amplio corpus bibliográfico ${ }^{59}$, alcanzó un importante medio de canalización social a través de la elaboración de carteles y postales alusivas, y muy especialmente de la cinematografía de la época. Títulos tan conocidos como Romancero marroqui (1939) ${ }^{60}$ o iHarka! (1941) reproducen fielmente los clichés del discurso oficial en su representación del «moro» y de la fraternidad hispano-marroquí ${ }^{61}$.

Sin embargo, a medida que los intereses del régimen no mostraban tanta dependencia para su supervivencia y consolidación con respecto a la situación de su protectorado, el discurso, que continuaba manteniendo el mismo pragmatismo y contenido ideológico de antaño, iba definiéndose en cuanto a la percepción del «moro». La capacidad de este último, una vez asentado el régimen tras la inestimable ayuda prestada por las tropas marroquíes, era limitada considerablemente al pasar de «hermano» a «hermano menor». Una mención esta última ausente en el discurso de Beigbeder, aunque inherente en su praxis, que ahora sí, era incluida de manera expresa en los textos africanistas de los años cuarenta y cincuenta.

En función de esta nueva coyuntura, se establecía una distinción que equivalía a eliminar cualquier atisbo de equiparación entre ambos pueblos, y a retomar, de manera más amable, los presupuestos coloniales de principios de siglo en virtud de los cuales el «moro» se contemplaba desde su situación de continua inferioridad con respecto al español. Esta gradación, al establecerse basándose en la falta de formación y capacitación técnica e intelectual del marroquí para labrarse su propio destino, se mostraba totalmente coherente

58 Véanse al respecto la información que aportan IBN `AZZŪZ ḤAKĪM, 1987a; 1987b; 1988; 1995. INFANTE, 2008. INIESTA, 2000; 2007.

59 De esta prolijidad durante el primer franquismo da buena muestra GIL GRIMAU, 1982.

60 ELENA, 1996: 83-120.

61 Véanse al respecto ELENA, 2002: 13-36. MARTÍN CORRALES, 1999: 392-396. VELASCO DE CASTRO, 2004: 211-218. 
con la determinación española de centrar su labor en el ámbito cultural, motor de desarrollo de cualquier pueblo. Pero, en realidad, el extraordinario protagonismo de la dimensión cultural en la política colonial y exterior del régimen obedecía a otros intereses.

En primer lugar, escenificaba una diferencia con respecto al colonialismo tradicional, lo que dotaba al protectorado español de unas peculiaridades que podían coadyuvar a dulcificar su imagen como dictadura y como potencia colonial. En consecuencia, la dimensión cultural del protectorado permitía establecer relaciones con los países árabes a través de las instituciones culturales creadas a tal efecto ${ }^{62}$, en plena lucha por salir de la condena internacional impuesta. En segundo término, la falta de capacitación constituía el principal elemento del que se sirvió el africanismo franquista de la época para justificar la presencia de España y su reticencia a conceder la autonomía - no digamos ya la independencia - a la Zona. En tercer lugar, las demandas nacionalistas eran encauzadas en su dimensión educativa y cultural, relegando las reivindicaciones políticas a un segundo plano con la consabida argumentación de que si no habían alcanzado la formación adecuada, no estaban en condiciones de hacerse cargo de las instituciones. La articulación de estas actuaciones se canalizó en el africanismo oficial a través del concepto de tutela. Una tutela cuyo alcance también fue reinterpretado a conveniencia en función de los intereses del momento.

\section{DE LA «HERMANDAD» A LA TUTELA DEL HERMANO MENOR MARROQUÍ}

Al término de la guerra civil, el relevo de Beigbeder al frente de la Alta Comisaría de España en Marruecos evidenciaba una evolución en el discurso africanista y en la percepción del «moro». Si a nivel político la implementación de instituciones culturales sirvió para contemporizar al nacionalismo ${ }^{63} \mathrm{y}$ para acercar posiciones con los países árabes ${ }^{64}$, las aspiraciones expansionistas del régimen, alentadas por el empuje del Eje en los primeros momentos del conflicto mundial, se mostraron de manera mucho más explícitas en un discurso que matizaba sensiblemente las consideraciones anteriores sobre el «moro» y la misión de España en Marruecos.

62 Véase una muestra de las mismas en VALDERRAMA MARTÍNEZ, 1956. DELGADO GÓMEZ-ESCALONILLA, 1992.

63 Para más información, véanse DELGADO GÓMEZ-ESCALONILLA, 1992: 227-231. GONZÁLEZ GONZÁLEZ, 23 (Murcia, 2007): 183-197.

64 Sobre las bases de la política árabe del franquismo, consúltese ALGORA WEBER, V/8-9 (Madrid, 1990): 93-100. Para un análisis del papel desempeñado por la política colonial en las relaciones exteriores del franquismo con el mundo árabe, véase VELASCO DE CASTRO, 2005. 
Las menciones a la España imperial y a la misión civilizadora se incrementaron en la misma medida que la «hermandad» era definida en términos de tutela. Ninguna novedad en cuanto a la ideología del discurso, pero sí una mayor visibilidad de las aspiraciones del franquismo. Éstas últimas, con Tánger como primera reivindicación del irredentismo español, se mostraron especialmente receptivas a las veleidades imperialistas del general expuestas en sus contactos con la Alemania nazi e impulsadas, a nivel interno por la creciente influencia de los fascismos a través de la Falange, y a nivel externo por el impulso del Eje durante los primeros momentos del conflicto mundial.

No obstante, las ambiciones expansionistas de Alemania e Italia pasaban también por el Norte de África y por hacerse con las colonias francesas, especialmente codiciadas por el gobierno de Franco. Asimismo, la falta de acuerdo con respecto a los términos en los que Hitler pretendía que España entrara en la guerra, unida a la rapidez con la que las autoridades francesas actuaron para defender sus posesiones, desembocaron en la firma del armisticio francoalemán, el 22 de junio de 1940. En consecuencia, si la caída de Francia, el 14 de junio, había dado alas al régimen y provocado la ocupación de Tánger, ocho días después, y en virtud de los términos acordados en el armisticio, las colonias francesas se mantendrían bajo la autoridad del gobierno galo. Con ello se rubricaba indefectiblemente el final del sueño imperial español, por lo que cualquier acuerdo posterior hubiera quedado en papel mojado.

Esta realidad histórica no tuvo su correspondencia en el africanismo del régimen, cuya línea discursiva mantuvo, con ciertos matices, el carácter irredentista hasta 1956. Como veremos en las siguientes páginas, aún durante la aparente y puntual dulcificación de la visión española con respecto al marroquí, el carácter eminentemente paternalista de la labor española, bajo el que subyacían los viejos tópicos en torno al «moro» como ser inferior y poco inteligente, de costumbres viciadas y sin civilizar ${ }^{65}$, no logró encubrirse, sino matizarse en momentos muy concretos y con una finalidad política específica.

Buena muestra de esta concepción y de la consiguiente imposición de la superioridad española, fue expresada por García Figueras en términos de «apostolado», al referirse al ejercicio de control e imposición de los interventores sobre las autoridades y la población marroquí. Con ello, establecía una nueva relación entre esta nueva Cruzada - desprovista ahora de algunas de las connotaciones medievales que no casaran con la imagen que se pretendía implantar-, y el imperialismo evangélico de la conquista de América:

Se trata, en efecto, de un verdadero apostolado, de una misión tutelar, de civilización, de comprensión, que ha de ejercerse con todas las virtudes y toda la abne-

65 Para una visión general sobre la tipología y estereotipos coloniales del moro, véanse MATEO DIESTE, 1997: 221-231. MARTÍN CORRALES, 37-1 (Madrid, 2007): 83-108. 
gación que del apostolado se derivan. Es sencillamente ganar para la civilización a aquellos pueblos, llevarles la luz del progreso: es, y ello constituye su motivo más importante, ganar para España el corazón de las poblaciones marroquíes que han sostenido con nosotros una lucha injustificada de siglos. La pacificación lograrán imponerla las armas, los corazones no se ganan más que con un apostolado de fe en el propósito, de justicia, de amor ${ }^{66}$.

La «hermandad», por tanto, no se producía en términos de igualdad, sino de sumisión del colonizado al colonizador. La imagen de un niño que necesita ser guiado, o la de un hermano menor que debe ser aleccionado, fueron empleadas con frecuencia para maquillar la supeditación que implicaba el mantenimiento del sistema de protección. García Figueras reproduce fielmente esta línea ideológica, en la que podríamos encontrar reminiscencias del mito del «buen salvaje» o del «moro amigo», a los que hay que instruir al permanecer éstos en una eterna minoría de edad política y social:

Marruecos podemos justamente asimilarlo a un pueblo menor de edad, a un niño que ha vivido en la libertad de sus impulsos, bajo el peso de errores ancestrales. Nuestra misión es la de un hermano mayor, que le toma bajo su tutela y con su consejo lo lleva por el buen camino ${ }^{67}$.

Otro elemento inherente al de la tutela era el de la idoneidad de quien debía ejercerla, pues sólo un pueblo que comparta lazos históricos y culturales comunes puede desempeñar su función de manera adecuada. En otras palabras, España gozaba de mayores derechos que otros países para «civilizar» a sus hermanos marroquíes:

Para que dos espíritus puedan entablar conversación, penetrar el uno en el otro, comunicarse y transmitirse lo que son, prestar guía y tutela el mayor al menor de edad, es preciso que exista entre ellos cierta consustancialidad, cierto parentesco, cierta homogeneidad, y esta homogeneidad sólo se engendra cuando les son comunes el medio natural y las tradiciones históricas ${ }^{68}$.

Como bien analiza Bachoud, «la dinámica nacional de la colonización implica cierta imagen del poderío de la patria, enunciada en términos económicos, militares, culturales, o en todos ellos a la vez, lo que justifica la exportación de un modelo de civilización hacia países menos favorecidos» ${ }^{69}$. De este modo, convertida en transmisora de la civilización y el progreso, acorde con la propaganda y el lenguaje del régimen, se imponía así una visión extrema-

66 GARCÍA FIGUERAS, 3/II-X (Madrid, 1934): 60.

67 GARCÍA FIGUERAS, 1926: 121.

68 GARCÍA FIGUERAS, 1966, vol. 1: 125.

69 BACHOUD, 1988: 29. 
damente condescendiente de la gestión colonial en el territorio, según la cual, España estaba llamada a «realizar una alta labor espiritual, para continuar la Historia de España como nación, para tratar con justicia y con amor a un pueblo hermano».

En un rasgo característico de la ideología colonial, la misión civilizadora, así como la hermandad a la que supuestamente se apelaba, encerraban una clara concepción eurocéntrica y paternalista de las relaciones con otros pueblos, considerados atrasados y a los que, en función de dicho sistema, se estaba legitimado a «civilizar». Es más, el concepto de «protectorado sentimental», incidía en la «labor civilizadora» de la Nación protectora, pues según Beigbeder, era la «única razón que justifica nuestra presencia entre estos hermanos marroquíes $\rangle^{70}$. Por lo que respecta al paternalismo, del que también encontramos numerosas muestras durante la etapa republicana, contamos con el testimonio de Cordero Torres, uno de los máximos representantes de la ideología colonial franquista, quien se refirió en reiteradas ocasiones a Marruecos como a un pueblo «menor de edad» al que había que tutelar:

I. Marruecos es un país cuya soberanía ha desaparecido transitoriamente, pero que la recobrará tan pronto desaparezcan los motivos, causantes de dicha pérdida por su capacitación total. Es interés de España, corno hermana mayor de Marruecos, ayudar a este país a su capacitación para conseguir tal independencia, estableciendo cuando llegue dicho momento relaciones de alianza perpetua.

II. Con tal fin corresponde a España ejercer funciones tutelares inspiradas en su misión universal y dentro del mayor respeto a la personalidad, tradición islámica e interés del pueblo marroquí, considerando al protectorado como sacrificio y deber y no como medio de beneficio material ${ }^{71}$.

En esta misma línea, los temas y contenidos desarrollados en la Academia de Interventores estaban concebidos desde este mismo prisma de supuesta hermandad: la función del interventor residía en tutelar a su homólogo marroquí en el desempeño de sus actividades, lo cual entrañaba una noción manifiesta de superioridad o bien de falta de capacitación marroquí para el desempeño de su cometido ${ }^{72}$.

Casi una década antes del estallido de la guerra civil, Gil Benumeya retomaba tópicos del pasado para sustentar un discurso paternalista y muy en la línea de lo que posteriormente constituirían las bases de la política colonial franquista:

70 BEIGBEDER ATIENZA, 1940: 12.

71 CORDERO TORRES, 1956: 18.

72 Para más información sobre la importancia de la función desempeñada por el sistema de intervenciones, considerado la «piedra angular» de la gestión colonial, véase VILLANOVA, 31 (Melilla, 2001): 385-404; 2002: 247-280. 
La labor pedagógica entre los indígenas no ha comenzado aún; es indispensable organizar nuestra enseñanza en la zona sobre una base patriótica marroquí, hay que hacer al moro amar a su patria, sentir su verdadero patriotismo "majzén" que anule los particularismos regionales y sea un baluarte contra extrañas intromisiones. El sentimiento nacional ha de surgir fatalmente y debe surgir a la sombra de España, la hermana mayor del pequeño Marruecos, de aquel Marruecos saadiano fuerte e independiente, aliado con Felipe II para la libertad del Estrecho y la gloria de la raza íbera ${ }^{73}$.

Por otra parte, este protectorado sentimental, basado en la ayuda a un hermano desvalido, implicaba también el carácter temporal de la misión civilizadora o tutelar ${ }^{74}$. Un elemento que las autoridades franquistas esgrimieron a conveniencia en sus relaciones con el nacionalismo de la Zona, al que trataron de contemporizar ${ }^{75}$.

La capacitación de los marroquíes para gestionar de manera autónoma las instituciones político-administrativas ya existentes, así como la posible transformación de la Zona en un sultanato independiente del protectorado francés centraron buena parte del debate entre autoridades franquistas y nacionalistas tetuaníes. La cuestión de fondo residía en la interpretación de los límites y alcances de la función tutelar, entendida por parte española en términos inmovilistas, lo que implicaba una insuficiente evolución intelectual y material del «moro».

Ya en 1933, fecha clave en la que conviene contextualizar el trasfondo de éstas y otras publicaciones, autores tan conocidos como Antonio Martín de la Escalera, argumentaba lo siguiente:

Somos, pues, unos tutores honrados; podemos ser siempre unos tutores honrados que ni pretenderemos ni necesitaremos la capitis diminutio indefinida de nuestro pupilo, con quien nos une un viejo parentesco ${ }^{76}$.

Pero ese momento no llegó ni en 1936, ni en 1942, ni tan siquiera en 1956. La tutela o eterna minoría de edad de Marruecos se utilizó como argumento principal para justificar el mantenimiento del sistema de protección, al que eufemísticamente Arqués definía como «guía del impulso renovador renacentista» de la civilización árabe e islámica:

Nuestro protectorado reanudó su obra y comenzó a trabajar. Nos apoyábamos en las tradiciones militares de España y en la posesión indiscutible del dominio.

73 GIL BENUMEYA, 21 (Madrid, 1926): 211.

74 GARCÍA FIGUERAS, RODA JIMÉNEZ, 1955, vol. 1: 108.

75 IBN 'AZZŪZ HaKĪM, 1999b: 148-211. Véase también YBARRA, 1993: 401-414; 1998: 65-78.

76 Citado por CORDERO TORRES, 1956: 24. 
Teníamos la fortuna, además, de que dos hombres predestinados estuvieran aquí para guiar el impulso renovador de este magnífico Renacimiento. Eran el Príncipe Muley el Hasán, Jalifa soberano de la Zona española, y el Teniente Coronel Beigbeder. El nombre de Franco tremolaba desde el principio como una bandera del Is$\operatorname{lam}^{77}$.

La identificación de Franco y de su régimen con los valores islámicos había constituido un hábil recurso en la captación de tropas y en el mantenimiento de la ficción de la recreación de un nuevo al-Andalus. En cualquier caso, esta línea de actuación basada en un discurso fraternal plagado de formulismos y expresiones grandilocuentes, en la exaltación de los valores comunes y en la promoción de las bondades de una política colonial supuestamente desligada de intereses particulares del régimen, se mantuvo oficialmente hasta la concesión de la independencia.

\section{EVOLUCIÓN DEL DISCURSO AFRICANISTA: LA PERCEPCIÓN DE MARRUECOS Y LOS MARROQUÍES TRAS LA INDEPENDENCIA}

El mismo día de la firma de los acuerdos hispano-marroquíes, en abril de 1956, Franco mantenía intacta su convicción de que Marruecos aún no estaba preparado para actuar con independencia del Gobierno español ${ }^{78}$. Meses antes, el anuncio de la abolición del tratado de Fez había supuesto un serio golpe a su empeño en continuar con el régimen de protección, el mismo empeño que empleó para ejercerlo en España durante dos décadas más. No obstante, diez años después de la independencia, en 1966, uno de los autores que con mayor dedicación había defendido las virtudes del ejercicio de un "protectorado sentimental», García Figueras, reivindicaba ahora una política pragmática (como si la anterior no lo hubiera sido), que sirviera a los intereses del país por encima de cualquier otra consideración:

Ni Inglaterra ni Francia hacen política exterior sentimental; hacen política inglesa y francesa, como nosotros debemos hacer política española. No nos empeñemos en exagerar gratitudes y adhesiones. Todo el secreto de nuestra diplomacia

77 ARQUÉS, 7 (Madrid, 1940): 15-16.

78 YBARRA, 1998: 265, menciona que Franco, el mismo día de las negociaciones hispano-marroquíes, «reconocía que la independencia parecería un poco prematura en ciertos aspectos, debido sobre todo al retraso y falta de preparación del pueblo marroquí»». Como contrapunto a esta opinión sobre la capacitación técnico-administrativa de los marroquíes de la zona jalifiana, véase el testimonio del que fuera alto funcionario marroquí de la Administración española en Marruecos: IBN AZZUZ ḤAKIM, 31 (Madrid, 1955): 27-36. 
consiste en hacer coincidir nuestros intereses con los de Inglaterra y Francia, nuestras aliadas naturales ${ }^{79}$.

Del fragmento anterior podrían extraerse interesantes reflexiones en torno a la política exterior del régimen y al papel de Marruecos en ella, pero se trata de una cuestión tan amplia como compleja que no abordaremos, al alejarse de nuestro tema de estudio. Únicamente mencionaremos que, entre los motivos del nuevo giro argumental esgrimido a partir de la independencia por destacados africanistas ${ }^{80}$, habría que recordar la problemática suscitada en torno al proceso de descolonización. La repercusión de este último, no sólo a nivel político, sino también social, se tradujo en unas conflictivas relaciones hispano-marroquíes ${ }^{81}$, y en la recuperación de algunos de los estereotipos del imaginario colectivo español en torno al «moro» ${ }^{82}$.

En cualquier caso, de esta lectura no cabe inferir modificación sustancial alguna en sus presupuestos; más bien concluir señalando la coherencia de ambos discursos, ya que expresan la misma idea: no existe política exterior que no base sus directrices en los intereses nacionales. De lo que se infiere que, a pesar de su carácter propagandístico, el «protectorado sentimental» no dejó de constituir la imposición de un sistema colonial, y con ello, de los intereses de la metrópoli sobre los pueblos sometidos al régimen de protección. Atrás quedaban los intentos, sinceros o no, de conciliar la gestión colonial con la concesión de una futura independencia. Y más aún, también se obviaban las propuestas que, dentro de la intencionalidad del régimen por permanecer en Marruecos bajo el sistema de protección, demandaban nuevas fórmulas de permanencia e influencia española en Marruecos, esto es, la compatibilidad entre los intereses españoles y los marroquíes a través de unas relaciones bilaterales cimentadas en los nexos de unión, y no en los elementos de fricción:

Ningún otro Estado que España se encuentra más curado de pretensiones imperialistas, ni sus egoísmos y sus legítimos intereses están más lejos de esas ambiciones. Todas nuestras posibilidades africanas son perfectamente compatibles con la libertad y la independencia del pueblo marroquí. Más todavía: hay un extenso sector de intereses comunes a España y Marruecos 83 .

79 GARCÍA FIGUERAS, 1966, vol. 2: 96.

80 Para más información, véase GIL GRIMAU, 2002: 49-62.

81 Véanse ALGORA WEBER, 31 (Melilla, 2001): 51-70. HERNANDO DE LARRAMENDI, 1997: 349-396. YBARRA, 1998: 263-280.

82 Véanse algunas muestras en MARTÍN CORRALES, 2002: 203-226.

83 Citado por CORDERO TORRES, 1956: 24. Cordero Torres ya se había expresado anteriormente en semejantes términos al afirmar que los deseos de los nacionalistas marroquíes: un Marruecos libre y unido, no eran incompatibles con los propósitos españoles 
Este fragmento de Antonio Martín de la Escalera ha de contextualizarse en el momento en el que fue escrito, 1933, pero también ha de interpretarse en clave de política exterior, constituyendo un punto de no retorno de la diplomacia española que veintitrés años más tarde, no supo, no pudo o no se quiso llevar a buen término durante las conversaciones tendentes a la obtención de la independencia.

En otras palabras, si abstraemos al discurso franquista en torno al Protectorado de los intereses coyunturales que dieron origen a su gestación y lo contextualizamos en términos de política exterior, encontraremos las claves de lo que en geo-política ha venido denominándose como "colchón de intereses», con los que no sólo se cimentan las relaciones internacionales, sino que se evitan posibles fracturas en las alianzas establecidas.

$\mathrm{Si}$ consideramos todas las argumentaciones que con otra intencionalidad articularon el africanismo español desde el siglo XIX y analizamos sus posibles repercusiones y aplicaciones en la política exterior española a partir de la independencia de Marruecos, podría concluirse que los vínculos históricos y culturales del pasado, unidos a factores geo-estratégicos, como la situación de nuestro país en el concierto regional mediterráneo y europeo, corroborarían algunas de las afirmaciones vertidas en las décadas de los treinta y los cuarenta. La primera de ellas, formulada por Martín de la Escalera, giraba en torno a la compatibilidad de los intereses españoles en un Marruecos independiente. La segunda, como subrayaba Arqués en 1942, el papel que la alianza hispanomarroquí podría desempeñar en un «compromiso de civilización euroafricana» ${ }^{84}$.

En cualquier caso, y como colofón a esta exposición, en la que hemos hecho mención de los fundamentos ideológicos que constituyeron las bases sobre las que se cimentó la imagen del «moro» en la política indígena y la maquinaria propagandística que la acompañó, queremos incluir una de las muestras más significativas del cambio efectuado en el discurso oficial entre la guerra del Rif y la guerra civil. Se trata de un manual de lecturas titulado La emoción de España, cuya edición de 1924 contrasta vivamente con la de 1937 y ésta, a su vez, con la de 1962, al añadirse y suprimirse determinados pasajes referentes a los marroquíes. Si en 1924, el manual incluía el siguiente párrafo, consecuencia inequívoca de Annual:

España ha recibido de Europa el encargo de civilizar el Norte de Marruecos, y lo hará, porque la característica de su vida en la Historia es sacrificarse por el progreso de los demás. En el gran teatro de la civilización musulmana los moros no

en el territorio. Véase CORDERO TORRES, 1946: 248.

84 ARQUÉS, 1942: 158. 
pueden ocupar un palco proscenio mientras sean como son. A España, la buena y la generosa, le ha dado el mundo el encargo de que los moros no sean como son ${ }^{85}$.

En 1937, la crítica se tornaba en súbito agradecimiento:

En el gran teatro de la civilización mediterránea, los moros, influidos por España, son hoy verdaderos enamorados de la hidalga nación española, por la que derraman generosamente su sangre en los campos de batalla contra los horrores de la barbarie roja. Los moros del protectorado español merecen todo el cariño y la gratitud de España porque vinieron en masa a pelear por la bandera española en la lucha contra el comunismo 86 .

Estas alteraciones, además de mostrar el alcance de la propaganda del régimen franquista y su preeminencia sobre la contra-propaganda francesa y republicana ${ }^{87}$, evidenciaron una realidad: la numerosa participación de tropas marroquíes en el bando nacional. Con ella se denotaba la intencionalidad e instrumentalización de la «hermandad hispano-marroquí», pues parece poco plausible considerar que en apenas once años, la actitud y consideración con respecto al marroquí cambiara de una manera tan radical ${ }^{88}$.

El agradecimiento que se desprende de este fragmento implica una política poco sentimental, nada espiritual y bastante interesada en la consolidación de la sublevación en la Península. Sin embargo, años más tarde, en la edición de 1962, el reconocimiento a la ayuda marroquí desaparecerá. Al igual que en el fragmento de García Figueras que incluíamos en líneas anteriores, la omisión bien podría haber estado condicionada por la realidad histórica del difícil momento por el que atravesaban las relaciones hispano-marroquíes, en las que la carencia de un colchón de intereses que aminorara las consecuencias de la problemática generada en torno al irredentismo marroquí -incluyendo la cuestión de las plazas de soberanía y el conflicto del Sáhara-, contribuyó a perpetuar la percepción del «moro» en clave negativa y opositora.

\section{CONCLUSIONES}

De lo expuesto en las páginas anteriores se concluye, en primer lugar, que la fluctuación entre la imagen del «moro» difundida durante la «campaña de

85 ABÓS SANTABÁRBARA, 2003: 49.

86 ABÓS SANTABÁRBARA, 2003: 366.

87 MERROUN, 2003: 39, menciona algunas de estas campañas emprendidas en la frontera con la Zona española, así como la activa labor de la Falange en Tánger.

88 Para más información, consúltese la panorámica que traza en su análisis MARTíN CORRALES, 2007: 83-108. 
pacificación", la divulgada durante el alistamiento de tropas marroquíes, la inferida de la participación de estas últimas en la guerra civil, la promovida durante la postguerra mundial, y la percibida a partir de la independencia del reino alauí, evidencian el pragmatismo utilitarista del franquismo y la sorprendente plasticidad de su discurso oficial, concebido en función de los intereses políticos del régimen en cada momento.

En segundo término, se infiere que la percepción y construcción de la imagen del «moro» discurre paralela a la dinámica histórica en la que se inserta el discurso africanista. Éste, a su vez, es fruto de los intereses políticos y vicisitudes históricas por las que transcurren las relaciones entre ambos países. De hecho, las crisis que cíclicamente sacuden las relaciones bilaterales desempeñan un importante papel en la potenciación de estos estereotipos, como podemos comprobar en la prensa española y marroquí de las últimas décadas.

En este sentido, la geografía desempeña un papel fundamental en la dinámica histórica de los pueblos, al propiciar los encuentros y desencuentros entre vecindades. No obstante, es la articulación política de las circunstancias y factores coyunturales y estructurales inherentes a determinada comunidad, la que interpreta y define en clave inclusiva o excluyente esta idiosincrasia. Por lo tanto, cabría colegirse que tanto durante la guerra colonial como durante la guerra civil, se produjo un proceso similar de etnificación del Otro, en virtud del cual tanto el «Otro» marroquí como el «Otro» español fueron construidos en torno a visiones reduccionistas que facilitaran su identificación ${ }^{89} \mathrm{y}$, en consecuencia, su oposición y enfrentamiento ${ }^{90}$.

De hecho, la visión del «moro» continúa dando lugar a discursos destinados al refuerzo identitario, a la distinción en clave opositora con respecto a un colectivo cercano. En este sentido, la evolución en la percepción del colectivo marroquí en torno a presupuestos relacionados con otras realidades más actuales no entraña, en su esencia, una gran diferencia con respecto a los presupuestos medievales con los que iniciábamos este recorrido. La connotación inherente en la alteridad con la que contemplamos al «moro», reafirma no sólo la identidad construida sobre binomios opositores, sino también la instrumentalización que a lo largo de la historia se ha hecho de ella en función de impulsar unas prácticas sociales afines a unos intereses determinados.

Por otra parte, los discursos edificados sobre la idealización del pasado compartido llegan a rozar en determinados momentos el folclorismo, y con ello participan del conjunto de clichés y estereotipos con los que percibimos de manera reduccionista un mundo heterogéneo, plural, complejo y en movi-

89 Una simplificación a la que contribuyó la reproducción de fotografías y carteles ilustrativos de estas imágenes contrapuestas del «moro», como bien analiza MARTÍN CORRALES, 1999: 375-399; $2002 \mathrm{~b}$.

90 BALFOUR, 2002: 522; 2003: 96. 
miento, como también lo es el nuestro. Sería deseable que la noción de «moro", que podríamos extrapolar a la de «árabe» y a la de «musulmán» en no pocos contextos, pudiera desmitificarse con respecto a la recreación del paraíso andalusí, en la misma medida que desvincularse de percepciones que lo asimilan a realidades que atentan contra las sociedades occidentales, tales como la delincuencia, la intolerancia, y muy especialmente, la violencia.

\section{BIBLIOGRAFÍA}

Abós Santabárbara, Ángel, La historia que nos enseñaron (1937-1975), Madrid, Akal, 2003.

Acedo Colunga, Felipe, «La aviación en África (II)», Revista de Tropas Coloniales, 4 (Ceuta, 1924): 13-14.

Algora Weber, $\mathrm{M}^{\mathrm{a}}$ Dolores, «La política árabe del régimen franquista: planteamientos generales y fases», Estudios Africanos, V/8-9 (Madrid, 1990): 93-100.

Algora Weber, $\mathrm{M}^{\mathrm{a}}$ Dolores, Las relaciones hispano-árabes durante el régimen de Franco. La ruptura del aislamiento internacional (1946-1950), Madrid, Ministerio de Asuntos Exteriores, 1995.

Algora Weber, $\mathrm{M}^{\mathrm{a}}$ Dolores, «El mundo árabe al inicio de la Guerra Fría: ¿descolonización o colonización?», Aldaba, 31 (Melilla, 2001): 51-70.

Arqués, Enrique, «El Alzamiento Nacional en África», Ejército. Revista Ilustrada de las Armas y Servicios, 7 (Madrid, 1940): 15-16.

Arqués, Enrique, El momento de España en Marruecos, Madrid, Ediciones de la Vicesecretaría de Educación, 1942.

Asín Palacios, Miguel, «Por qué lucharon a nuestro lado los musulmanes marroquíes», en Asín Palacios, Miguel, Obras escogidas, Madrid, s.n., 1948, vol. II-III: 125-152.

Bachoud, Andrée, Los españoles ante las campañas de Marruecos, Madrid, Espasa Calpe, 1988.

Balfour, Sebastian, Abrazo mortal. De la guerra colonial a la Guerra Civil en Españ y Marruecos (1909-1939), Barcelona, Península, 2002.

Balfour, Sebastian, «El otro moro en la guerra colonial y guerra civil», en González Alcantud, José Antonio (ed.), Marroquies en la guerra civil española: campos equivocos, Barcelona, Antrophos, 2003.

Barcia, Augusto, «El problema de Marruecos. La indiferencia nacional el mayor enemigo», Revista de Tropas Coloniales, 3 (Ceuta, 1924): 9-10.

Beigbeder Atienza, Juan, «Discurso pronunciado por el Alto Comisario de España en Marruecos, Coronel Juan Beigbeder en el acto en que el filósofo libanés. Amin er-Rihani fue nombrado director honorario del Centro de Estudios Marroquíes de Tetuán (20 de junio de 1939)», Larache, Instituto General Franco de Estudios e Investigación Hispano-Árabe, 1940. 
Beltrán y de Torres, Francisco, El libro y la imprenta con máximas, aforismos, noticias y disertaciones de diversos autores antiguos y modernos y 143 viñetas «al servicio de los libros», Madrid, Francisco Beltrán Editor, 1931.

Benjelloun, Abdelmajid, «La causa de la participación de marroquíes en la guerra civil española (1936-1939)», en González Alcantud, José Antonio (ed.), Marroquíes en la guerra civil española: campos equívocos, Barcelona, Antrophos, 2003: 42-57.

Berenguer, Dámaso, Campañas en el Rif y Yebala, 1921-1922. Notas y documentos de mi diario de operaciones, Madrid, Sucesores de R. Velasco, 1923.

Castién, Ignacio, «El Marruecos contemporáneo. El peso de la herencia colonial y precolonial», en Castién Maestro, Ignacio y Abdel-Karim, Gamal (eds.), Sociedad y política en el mundo mediterráneo actual, Madrid, Instituto Egipcio de Estudios Islámicos, 2007.

Cordero Torres, José $\mathrm{M}^{\mathrm{a}}$, La misión africana de España, Madrid, Ediciones de la Vicesecretaría de Educación Popular, 1941.

Cordero Torres, José $\mathrm{M}^{\mathrm{a}}$, «El concepto español del Protectorado», en Alta Comisaría de España en Marruecos, Labor de España en África. Conferencias organizadas por la sección informativa de Economía Marroquí de Barcelona, Barcelona, 1946.

Cordero Torres, José $\mathrm{M}^{\mathrm{a}}$, El africanismo en la cultura hispánica contemporánea, Madrid, Cultura Hispánica, 1949.

Cordero Torres, José $\mathrm{M}^{\mathrm{a}}$, «El pensamiento español sobre Marruecos: problemas nuevos, criterios perennes», Cuadernos de Estudios Africanos, 35 (Madrid, 1956): 9-40.

Costa, Joaquín, «Intereses de España en Marruecos. Discursos pronunciados en el encuentro celebrado en el Teatro de la Alhambra el día 30 de marzo de 1884, por los señores D. Francisco Coello, D. Joaquín Costa, D. Gabriel Rodríguez, D. Gumersindo de Azcárate, D. Eduardo Saavedra y D. José de Carvajal», Madrid, CSIC-IdEA, 1951.

Delgado Gómez-Escalonilla, Imperio de papel. Acción cultural y política exterior durante el primer franquismo, Madrid, CSIC, 1992.

Egido, Ángeles y Aróstegui, Julio, Memoria de la Segunda República: mito y realidad, Madrid, Biblioteca Nueva, 2006.

Elena, Alberto, «Romancero marroquí: africanismo y cine bajo el franquismo», $S e$ cuencias: Revista de historia del cine, 4 (Madrid, 1996): 83-120.

Elena, Alberto, «Políticas cinematográficas coloniales: España, Francia y el Protectorado de Marruecos», en Rodríguez Mediano, Fernando y de Felipe Rodríguez, Helena (coords.), El protectorado español en Marruecos: gestión colonial e identidades, Madrid, CSIC, 2002: 13-36.

Ferrando de la Hoz, Vicente, Apuntes para la historia de la Imprenta en el Norte de Marruecos, Tetuán, Instituto General Franco de Estudios e Investigación Hispano-Árabe, 1949.

Franco, Francisco, «Pasividad e inacción», Revista de Tropas Coloniales, 4 (Ceuta, 1924): 4. 
Franco, Francisco, «Facetas del Protectorado», África. Revista de Tropas Coloniales, 21 (Madrid, 1926): 265-266.

García Figueras, Tomás, Temas de protectorado, Imprenta Tropas Coloniales, 1926.

García Figueras, Tomás, «Hacia un Protectorado eficiente. La vocación del interventor», África, 3/II-X (Madrid, 1934): 59-60.

García Figueras, Tomás, Reivindicaciones de España en el Norte de África. Conferencia pronunciada el 4 de octubre de 1942 en el Teatro Central de Barcelona, Madrid, s.n., 1944.

García Figueras, Tomás y Roda Jiménez, Rafael de, Economía social de Marruecos, Madrid, CSIC-IdEA, 1955, 2 vols.

García Figueras, Tomás, La acción africana de España en torno al 98. De la crisis de la política africana, 1898, al Protectorado de Marruecos, 1912, Madrid, Instituto de Estudios Africanos, 1966, 2 vols.

Gil Benumeya, Rodolfo (pseud.Benomar), «Los tres puntos fundamentales de nuestra política indígena», África. Revista de Tropas Coloniales, 21 (Madrid, 1926): 211.

Gil Grimau, Rodolfo, Aproximación a una bibliografía española sobre el norte de África: 1850-1980, Madrid, Ministerio de Asuntos Exteriores, 1982.

Gil Grimau, Rodolfo, «Corrientes ideológicas internas en el africanismo español», en VVAA., Actas del Congreso Internacional El Estrecho de Gibraltar, Ceuta, 1988, vol. 3: 277-285.

Gil Grimau, Rodolfo, «Evolución del pensamiento africanista español ante la descolonización del Magrib, durante el período 1945-1975», en Gil Grimau, Rodolfo, La frontera al Sur de al-Andalus. Estudios sobre la Península Ibérica y sus relaciones históricas con Marruecos, Tánger, Asociación Tetuán Asmir, 2002: 49-62.

González González, Irene, "La «hermandad hispano-árabe» en la política cultural del franquismo (1936-1956)», Anales de Historia Contemporánea, 23 (Murcia, 2007): 183-197.

Goytisolo, Juan, Crónicas sarracinas, Madrid, Ruedo Ibérico, 1982.

Halstead, Charles Raymond, "A 'Somewhat Machiavellian Face': Colonel Juan Beigbeder as High Comissioner in Spanish Morocco, 1937-1939”, The Historian, 37 (Ohio, 1974): 46- 66.

Hernando de Larramendi, Miguel, La politica exterior de Marruecos, Madrid, Mapfre, 1997.

Ibn Azzuz Hakim, Moḥammed, «La capacitación técnico-administrativa de los marroquíes de la zona jalifiana de Marruecos», Cuadernos de Estudios Africanos, 31 (Madrid, 1955): 27-36.

Ibn Azzuz Hakim, Muḥammad, Ab al-ḥaraka al-wațanīya al-magribīya al-ḥaŷy e Abd al-Sallām Binnūna. Hayātu-hu wa niḍālu-hu, 4 vols.: Rabat, al-Sāḥil, 1987a (vol. 1) y al-Hilāl al- Arabī, 1987b (vol. 2), al-Sāḥil, 1988 (vol. 3) y Mitāq al-Magrib, 1995 (vol. 4). 
Ibn Azzuz Hakim, Moḥammad, La actitud de los moros ante el alzamiento: Marruecos 1936, Málaga, Algazara, 1997.

Ibn Azzuz Hakim, Muḥammad, «Una visión realista del Protectorado ejercido por España en Marruecos», en VVAA., Actas del Encuentro España-Marruecos. Diálogo y Convivencia, Tetuán, Asociación Tetuán Asmir, 1999a: 54-55.

Ibn Azzuz Hakim, Muḥammad, F̄̄ rikāb za'ìm al-waḥda. Yawmiyāt amīn sirr alustād 'Abd al-Jāliq Turrīs, Tetuán, al-Jaliŷ al-'arabī, 1999b.

Infante, Blas, Andalucía: teoría y fundamento político. Blas Infante, Córdoba, Almuzara, 2008.

Iniesta, Enrique, Blas Infante: toda su verdad, Granada, Comares, 2000 (vols. 1 y 2), Córdoba, Almuzara, 2007 (vol. 3).

Jackson, Gabriel, Memorias de un historiador, Barcelona, Crítica, 2008.

Lyautey, Pierre (comp.), Lyautey l'africain: textes et lettres du Maréchal Lyautey, París, Plon, 1953, 4 vols.

Madariaga, $\mathrm{M}^{\mathrm{a}}$ Rosa de, «Árabes y españoles: complicidades y recelos mutuos», Revista Internacional de Sociología, 46 (Madrid, 1988): 509-520.

Madariaga, $\mathrm{M}^{\mathrm{a}}$ Rosa de, Los moros que trajo Franco: la intervención de tropas coloniales en la Guerra Civil española, Barcelona, Martínez Roca, 2002.

Madariaga, Ma Rosa de, «La guerra colonial llevada a España: las tropas marroquíes en el ejército franquista», en González Alcantud, José Antonio (ed.), Marroquíes en la guerra civil española: Campos equívocos, Barcelona, Anthropos, 2003: 58-94.

Maestre, Pedro, «La lealtad del indígena», Revista de Tropas Coloniales, 4 (Ceuta, 1924): 24-25.

Martín Corrales, Eloy, «Imágenes del Protectorado de Marruecos en la pintura, el grabado, el dibujo, la fotografía y el cine», en Nogué, Joan y Villanova, Josep Lluís (eds.), España en Marruecos. Discursos geográficos e intervención territorial, Lleida, Milenio, 1999: 392-396.

Martín Corrales, Eloy, «Entre el "moro" violador y el "moro" seductor: la imagen de los marroquíes en la guerra civil según las fuerzas republicanas», en López García, Bernabé y Ramírez, Ángeles (coords.), Antropología y antropólogos en Marruecos: homenaje a David M. Hart, Barcelona, Bellaterra, 2002a: 221-236.

Martín Corrales, Eloy, La imagen del magrebi en España. Una perspectiva histórica siglos XVI-XX, Barcelona, Bellaterra, 2002b.

Martín Corrales, Eloy, «Marruecos y los marroquíes en la propaganda oficial del Protectorado (1912-1956)», Mélanges de la Casa de Velázquez, 37-1 (Madrid, 2007): 83-108.

Mateo Dieste, Josep Lluís, El «moro» entre los primitivos: el caso del protectorado español, Barcelona, Fundación La Caixa, 1997.

Mateo Dieste, Josep Lluís, La «Hermandad» hispano-marroquí: politica y religión bajo el protectorado español en Marruecos (1912-1956), Barcelona, Edicions Bellaterra, 2003. 
Mola, Emilio, «La estrategia militar en Marruecos: la emboscada», África. Revista de Tropas Coloniales, 14 (Madrid, 1926): 106-107.

Mola, Emilio, Obras completas, Valladolid, Librería Santarén, 1940.

Morales Lezcano, Víctor, Africanismo y orientalismo español en el siglo XIX, Madrid, UNED, 1988.

Morales Lezcano, Víctor, «El Norte de África, estrella del orientalismo español», Awrāq, 11 (Madrid, 1990): 17-34.

Morales Lezcano, Víctor, España y el mundo árabe. Imágenes cruzadas, Madrid, ICMA, 1993.

Nerín, Gustau y Bosch, Alfred, El imperio que nunca existió. La aventura colonial discutida en Hendaya, Barcelona, Plaza \& Janés, 2001.

Nerín, Gustau, La guerra que vino de África, Madrid, Crítica, 2005.

Parra Monserrat, David, «El Magreb y «la buena y tradicional postura nacional». Las relecturas del africanismo decimonónico durante el franquismo», en VVAA., Nuevos horizontes del pasado: culturas políticas, identidades y formas de representación. Actas del X Congreso de la Asociación de Historia Contemporánea, Santander, Universidad de Cantabria, 2010 (en prensa).

Paz, Abel, La cuestión de Marruecos y la República española, Madrid, Fundación de Estudios Libertarios Anselmo Lorenzo, 2000.

Preston, Paul, La política de la venganza: el fascismo y el militarismo en la España del Siglo XX, Madrid, Península, 1997.

Preston, Paul, Franco «Caudillo de España», Barcelona, Grijalbo Mondadori, 1998a (6 $6^{\mathrm{a}}$ reimp.).

Preston, Paul, Las tres Españas del 36, Barcelona, Plaza \& Janés, 1998 b.

Ruiz Bravo-Villasante, Carmen, Un testigo árabe del siglo XX: Amîn al-Rîhânî en Marruecos y en España (1939). Traducción de Al-Magrib al-Aqşà y Nûr alAndalus, Madrid, Cantarabia, 1993.

Ruiz Trillo, Leopoldo, «Algo sobre las primeras Fuerzas Regulares», Revista de Tropas Coloniales, 2 (Ceuta, 1924): 6-7.

Valderrama Martínez, Fernando, Historia de la acción cultural de España en Marruecos (1912-1956), Tetuán, Editora Marroquí, 1956, 2 vols.

Velasco de Castro, Rocío, «¡Harka! exponente del cine colonial español», en Torres García, Ana, Velasco de Castro, Rocío (eds.), El Magreb hoy: estudios sobre historia, sociedad y cultura, Sevilla, Alfar, 2004: 211-218.

Velasco de Castro, Rocío, «El protectorado de España en Marruecos y su repercusión en la política árabe del franquismo», en Ortiz Heras, Manuel (ed.), Memoria histórica del franquismo: V Encuentro de Investigadores sobre el franquismo. Cuenca, Universidad de Castilla La Mancha, 2005.

Velasco de Castro, Rocío, «Arabismo y colonialismo español: Pascual de Gayangos y la cuestión marroquí», Norba. Revista de Historia, 22 (Cáceres, 2010): 245-262. 
Vernier, Pascal, "Les débuts de la carrière coloniale de Lyautey, Indo-Chine, Madagascar, Algérie et Maroc oriental (1894-1912)", Tesis doctoral, Universidad de Marsella I, 1993.

Villanova, Josep Lluís, «La academia de interventores del Protectorado de España en Marruecos», Aldaba, 31 (Melilla, 2001): 385-404.

Villanova, Josep Lluís, «La formación de los interventores en el Protectorado español en Marruecos (1912-1956)», en Rodríguez Mediano, Fernando y de Felipe, Helena (eds.), El Protectorado español en Marruecos. Gestión colonial e identidades, Madrid, CSIC, 2002: 247-280.

Ybarra Enríquez de la Orden, Concepción, «Acción política española en la independencia de Marruecos (1951-1956)», en Tusell, Javier, (coord.), El régimen de Franco (1936-1975): politica y relaciones exteriores, Madrid, UNED, 1993: 401-414.

Ybarra Enríquez de la Orden, Concepción, España y la descolonización del Magreb. Rivalidad hispano-francesa en Marruecos (1951-1961), Madrid, UNED, 1998.

Recibido: 08/11/2011

Aceptado: 30/07/2012 